University of Nebraska - Lincoln

DigitalCommons@University of Nebraska - Lincoln

Faculty Publications: Department of Entomology

Entomology, Department of

1996

\title{
Oviposition and Calling Behavior of Codling Moth (Lepidoptera: Tortricidae) in the Presence of Codlemone
}

Thomas J. Weissling

University of Nebraska-Lincoln, tweissling2@unl.edu

Alan L. Knight

Yakima Agricultural Research Laboratory

Follow this and additional works at: https://digitalcommons.unl.edu/entomologyfacpub

Part of the Entomology Commons

Weissling, Thomas J. and Knight, Alan L., "Oviposition and Calling Behavior of Codling Moth (Lepidoptera: Tortricidae) in the Presence of Codlemone" (1996). Faculty Publications: Department of Entomology. 319. https://digitalcommons.unl.edu/entomologyfacpub/319

This Article is brought to you for free and open access by the Entomology, Department of at DigitalCommons@University of Nebraska - Lincoln. It has been accepted for inclusion in Faculty Publications: Department of Entomology by an authorized administrator of DigitalCommons@University of Nebraska - Lincoln. 


\title{
Oviposition and Calling Behavior of Codling Moth (Lepidoptera: Tortricidae) in the Presence of Codlemone
}

\author{
THOMAS J. WEISSLING AND ALAN L. KNIGHT
}

Yakima Agricultural Research Laboratory, USDA-ARS, 3706 W. Nob Hill Boulevard, Yakima, WA 98902

\begin{abstract}
Ann. Entomol. Soc. Am. 89(1): 142-147 (1996)
ABSTRACT The effect of the major component of codling moth, Cydia pomonella (L.) sex pheromone (codlemone, E,E-8,10-dodecadien-1-ol) on female calling and oviposition behavior was investigated. Calling by virgin females was similar between moths placed in sealed containers containing codlemone or codlemone-free air. However, when pheromone emitted by females was removed by a continuous air stream, calling in codlemone-permeated air was significantly higher than in clean air. The temporal pattern of calling was unaltered by the presence of codlemone. In a laboratory no-choice test, oviposition rates by codling moth females were similar in the presence of codlemone and in codlemone-free air. However, in paired-choice tests, females deposited more eggs on uncontaminated waxed paper surfaces than on codlemone-contaminated surfaces.
\end{abstract}

KEY WORDS Cydia pomonella, female behavior, pheromone, codlemone, oviposition, calling

MATING DISRUPTION IS becoming increasingly important for management of codling moth, Cydia pomonella (L.) (Barnes et al. 1992, Howell et al. 1992, Pfieffer et al. 1993) and has raised several fundamental questions about moth behavior in the presence of pheromone constituents. The attraction of males to the principle component of the female-produced sex pheromone of codling moth, codlemone (E,E-8,10-dodecadien-1-ol [Roelofs et al. 1971]), has been thoroughly studied (Batiste et al. 1973). However, although it is known that female antennae detect codlemone (Barnes et al. 1992), little is known about the effect of codlemone-permeated air on the reproductive behavior of codling moth females.

Codling moth mating generally occurs high in the orchard canopy (Weissling and Knight 1995) and is entrained to photoperiod, normally taking place during evening twilight (reviewed in Howell 1991). Calling females assume a characteristic position on tree branches or leaves, and release pheromone primarily during the scotophase (Niemczyk et al. 1977, Castrovillo and Cardé 1979). Males responding to a pheromone plume land near the female and search in an ambulatory pattern while vigorously fanning their wings (Fluri et al. 1974). Though apparently not essential, visual cues play a role in final guidance of a responding male to the female (Hutt and White 1977, Castrovillo and Cardé 1980).

In apple, $\approx 57$ and $35 \%$ of eggs deposited by codling moth females are on the upper, and lower leaf surfaces, respectively, whereas only $8 \%$ of eggs are laid directly on fruit (Jackson 1979). Oviposi- tion is reported to occur before the onset of scotophase (Riedl and Loher 1980).

A better understanding of female behavior in the presence of codlemone is essential to evaluate fully the mating-disruption technique. The objectives of this study were to determine the effect of codlemone on the calling and oviposition behavior of codling moth females.

\section{Materials and Methods}

Calling Behavior. A series of experiments was conducted to determine if exposure to codlemone alters the frequency and temporal pattern of calling in codling moth females. Experimental moths were 2- to 3-d-old, laboratory-reared, virgin females from the USDA-ARS colony at Yakima. Experiments were conducted at $22 \pm 2^{\circ} \mathrm{C}$. Light levels were controlled by a series of time clocks connected to different incandescent light sources during 60-min dusk (0900-1000 hours) and sunrise (1800-1900 hours) periods. Light level at full illumination was 360 lux, and decreased at dusk in 20 min steps to 114,18 , and 7 lux. Moths were entrained to this photoperiod while in the pupal stage. The room in which experiments were conducted was illuminated with a red light during scotophase which was bright enough to make observations (4.3 lux).

Initial observations were made on moths placed in sealed containers either with or without codlemone. One female was placed in each of 20 plastic petri dishes ( 15 by $60 \mathrm{~mm}$ ) ( 10 dishes per treatment). Into each dish, a methylene chloride-rinsed 


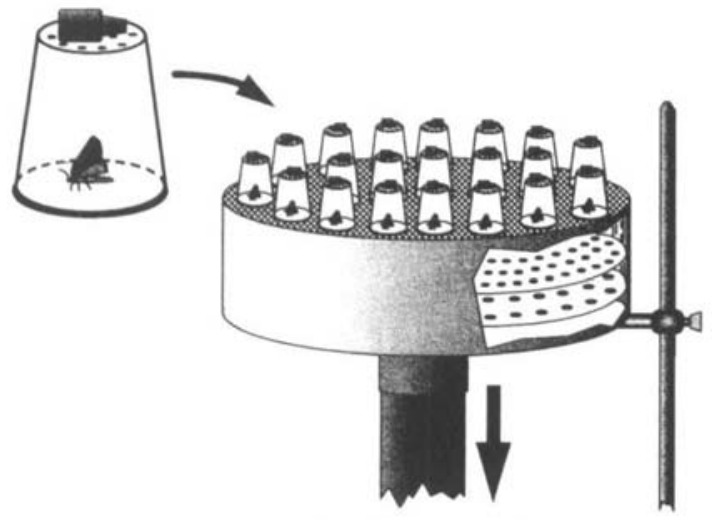

To Blower Motor

Fig. 1. Device used to pull air through individual plastic cups containing virgin codling moth females. Untreated and codlemone-treated $(1 \mathrm{~g})$ rubber septa placed on top of cups provided clean or codlemone-contaminated air.

and dried filter paper disk (2.3 cm diameter) or a disk treated with $100 \mu \mathrm{g}$ codlemone (dispensed in methylene chloride) was added $1 \mathrm{~h}$ before the beginning of dusk. Observations on calling activity commenced 30 min later and continued at $30-\mathrm{min}$ intervals until beginning of the photophase. Females were considered to be calling when the ovipositor was protruding from the abdomen and directed ventrally (Castrovillo and Cardé 1980). The experiment was repeated on 6 different dates, for a total of 60 females per treatment.

A 2nd test was conducted to determine if air flow interfered with the frequency of female calling. A device that pulled air through a mesh-covered platform was constructed (Fig. 1). A clear plastic tube, $30.2 \mathrm{~cm}$ i.d., $10 \mathrm{~cm}$ deep, was covered with tightly stretched, fine nylon organdy mesh. Two baffles were used to spread air flow evenly across the surface. The 1st baffle, located $4 \mathrm{~cm}$ below the mesh platform, was a circular disk with 390 holes ( $3 \mathrm{~mm}$ diameter) drilled through it. Holes were evenly spaced at $13 \mathrm{~mm}$ (center to center). Two centimeters below the lst disk was another plastic baffle with 84 holes $(6 \mathrm{~mm}$ diameter) drilled through it. Holes on this disk were spaced $27 \mathrm{~mm}$ apart (center to center). The bottom of the device was solid plastic with a $9 \mathrm{~cm}$ i.d. exhaust port attached to the center. The entire apparatus was placed on a ring stand, and a flexible hose (10.2 cm i.d.) was attached from the exhaust port to a blower motor. Air was exhausted to outside the room. Air speed (measured with a hot wire anemometer) was controlled by a variable resistor attached to the blower motor, and was set at the surface of the mesh-covered platform at $15 \mathrm{~cm} / \mathrm{s}$. Chambers for individual moths were $30-\mathrm{ml}$ clear plastic cups with 7 evenly spaced holes $(2 \mathrm{~mm}$ diameter) drilled through the bottom. Cups were inverted and placed on top of plastic petri dish (60 by $15 \mathrm{~mm}$ ) bottoms. Half of the bottoms had 16 holes ( $2 \mathrm{~mm}$ diameter) drilled through them. Cups were placed over these holes. Air flow through cups with perforated petri dishes was $8 \mathrm{~cm} / \mathrm{s}$. Observations of calling were as described above $(n=$ 48).

A 3rd test was conducted to determine the effect of codlemone-contaminated air on calling behavior in the presence of air flow. Procedures were as described above except that petri dish bottoms were omitted and inverted cups were placed direcily on the mesh. Air flow through cups was 1.0 $\mathrm{cm} / \mathrm{s}$. Red rubber septa, either blank or impregnated with $1 \mathrm{mg}$ codlemone were placed on top of each cup. Using the evaporative rate equation of McDonough (1991), release rate of codlemone from red rubber septa used in this experiment was calculated at $0.93 \mu \mathrm{g} / \mathrm{h}$. Turbulence of air and subsequent mixing of codlemone with air in chambers was confirmed by observing the flow of smoke (fuming sulfuric acid) introduced above cups. Observations on calling were as described above $(n=$ 60 ).

Data for all experiments were converted to percentage of calling for 2 -h time periods $(0-2,2-4$, $4-6$, and $6-8 \mathrm{~h}$ past lights out). Differences between treatments (untreated, codlemone-treated or still air, moving air) for each test were analyzed by the Kruskal-Wallis test (chi-square approximation) (SAS Institute 1985) within each 2 -h calling period.

Oviposition Behavior. Effects of codlemone on oviposition activity were studied in the laboratory. All moths used in studies were obtained from the USDA-ARS laboratory colony at Yakima and were mated 1-2 d after emergence. At the end of each experiment, females were dissected to determine the presence of spermatophores. Only eggs laid by mated females were used in data analysis. Light levels used during tests and entrainment were as previously described except that scotophase was 1 $\mathrm{h}$ longer $(9 \mathrm{~h})$.

Effect of Amount of Codlemone on Oviposition. Mated females were exposed to different amounts of codlemone. Females were individually placed in clear $30-\mathrm{ml}$ plastic cups that had been lined with waxed paper. Codlemone was dissolved in hexane and applied to filter paper disks $(2.3 \mathrm{~cm}$ diameter) for rates of $0.001,1,100$, and $1,000 \mu \mathrm{g}$ per disk. An untreated control consisted of a filter disk treated with clean hexane. After the solvent had evaporated, disks were placed in the bottom of cups and cups were sealed with parafilm. Eggs were counted after $24 \mathrm{~h}$.

Data were converted to eggs per mated female and analyzed by analysis of variance (ANOVA) (SAS Institute 1985).

Effect of Codlemone on Oviposition Choice. Codling moths were exposed to a codlemone impregnated surface to determine effect on oviposition. Mated females were individually confined to clear acrylic tubes $(2.5 \mathrm{~cm}$ i.d. by $15 \mathrm{~cm}$ long) enclosed at each end by mesh held in place with elas- 


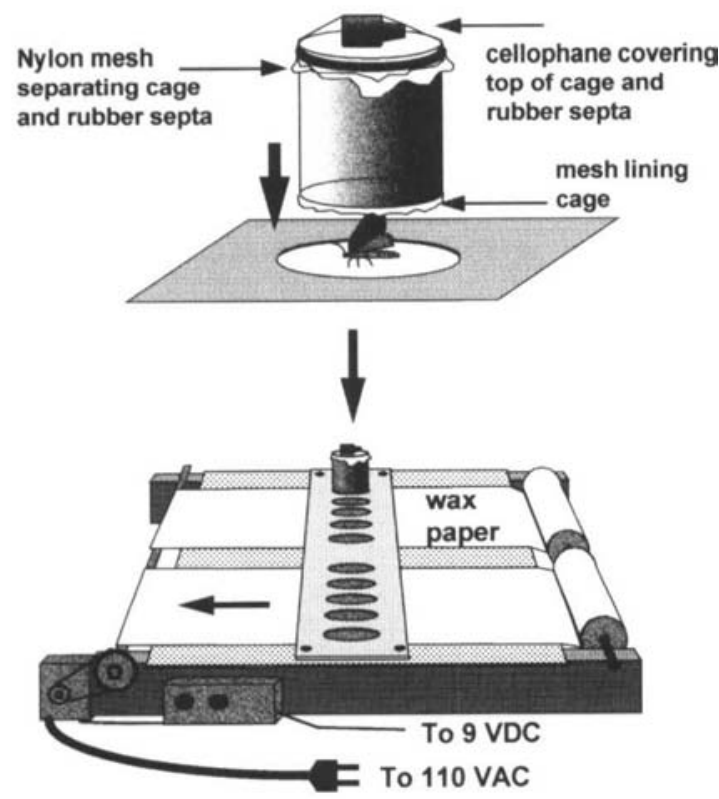

Fig. 2. Device to quantify temporal pattern of oviposition in codling moths (modified from Riedl and Loher [1980]). A small motor advanced the waxed paper once every hour. Moths were placed individually in the small cages that were situated just above the waxed paper. Above each cage was an untreated or codlemone-treated (1 g) rubber septa.

tic bands. Each tube was lined with waxed paper that was either exposed for $24 \mathrm{~h}$ to a fresh Isomate $\mathrm{C}$ pheromone dispenser (Shin Etsu, Tokyo, Japan [60.5\% codlemone, $31.8 \%$ dodecanol, and $7.7 \%$ tetradecanol]) held in a 1.5-liter sealed container, or untreated. Eggs were counted after $24 \mathrm{~h}$.

Mated females were allowed to make a choice between an untreated and a Isomate C-exposed surface for oviposition. Mated females were confined as described above except that half of each tube was lined with Isomate C-treated waxed paper, the other half with clean waxed paper. Data from both experiments were converted to eggs deposited per mated female and analyzed as a paired sample $t$-test (SAS Institute 1985).

Effect of Codlemone on Temporal Pattern of Oviposition. A device modified from that described by Riedl and Loher (1980) was used to advance waxed paper at specific time intervals and used to determine if the presence of codlemone influenced the temporal pattern of oviposition in codling moth (Fig. 2). The apparatus was mounted on a wooden frame $78 \mathrm{~cm}$ wide by $61 \mathrm{~cm}$ deep. Across the frame a $1 \mathrm{~cm}$ thick piece of clear acrylic $30 \mathrm{~cm}$ wide was placed. Spaced $2 \mathrm{~mm}$ above this was another piece of clear acrylic $14 \mathrm{~cm}$ wide. Ten holes (3.2 cm i.d., $6 \mathrm{~cm}$ apart center to center) were drilled into this piece. Two rolls of waxed paper were placed on a feeder spindle and threaded under the upper piece of clear acrylic. The waxed paper was attached to a take up spindle

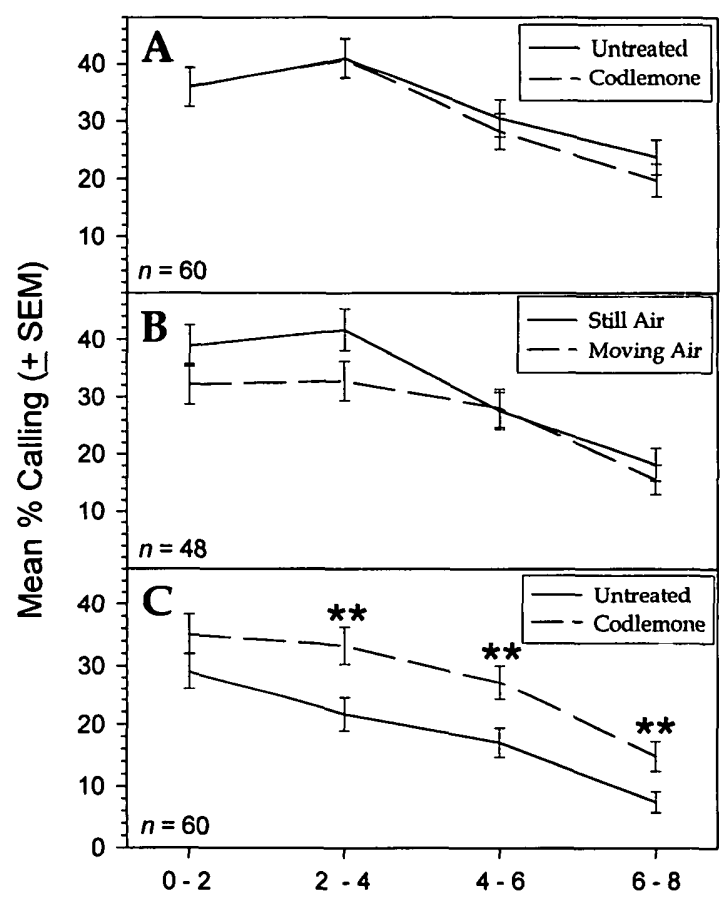

Hours past "lights-out"

Fig. 3. Mean percent \pm SEM codling moth female calling in sealed containers (A), in still or moving air (no codlemone) (B), and in moving air permeated with codlemone or left untreated (C). Significant statistical differences between treatments within a time period are indicated by asterisks (Kruskal-Wallis test; $P<0.05$ ).

which was attached by a rubber belt to a $1 \mathrm{rpm}$ DC motor. A timer circuit, powered by a 9 VDC source was used to time duration of each event (on off) and was controlled by a combination of a variable resistor and a capacitor. The timer circuit operated a relay which was used to run the motor. The rolls of waxed paper were automatically advanced $\approx 5 \mathrm{~cm}$ every hour. Slightly above each roll of waxed paper were 5 acrylic tubes $(3 \mathrm{~cm}$ high, $3.2 \mathrm{~cm}$ i.d.) lined with fine mesh that extended a few $\mathrm{mm}$ beyond the bottom. The top was first covered with mesh and on top of the mesh a red rubber septa was placed. Septa were covered by a thin plastic film. All coverings were secured by elastic bands. For each test, half of the septa were treated with $1 \mathrm{mg}$ codlemone. One female was placed in each cup, the cups were positioned on the apparatus, and the experiment was run for 48 $96 \mathrm{~h}$. The number of eggs deposited per mated female per hour was determined for each day.

\section{Results}

Calling Behavior. Calling rates were statistically similar between females in sealed containers with and without codlemone (Fig. 3A). Calling by moths exposed to still air was higher during the lst 
Table 1. Oviposition of codling moths exposed to various amounts of codlemone (E,E-8,10-dodecadien-1-ol) on filter paper disks $(2.3 \mathrm{~cm}$ diameter $)$ placed in sealed chambers

\begin{tabular}{ccc}
\hline \hline Dose, $\mu \mathrm{g}$ & $n$ & $\begin{array}{c}\text { Mean eggs/female } \\
\pm \text { SEM }\end{array}$ \\
\hline 0 & 25 & $30.9 \pm 4.7$ \\
0.001 & 27 & $35.2 \pm 3.7$ \\
1 & 3.1 & $30.9 \pm 4.0$ \\
1.00 & 19 & $33.1 \pm 6.7$ \\
1,000 & 21 & $25.4 \pm 5.6$ \\
\hline
\end{tabular}

4 hours of the scotophase than moths exposed to moving air (Fig. 3B). However, the percentage of calling females was not statistically different between these treatments. Females exposed to codlemone-permeated moving air called more frequently than females exposed to clean moving air (Fig. 3C). This difference was significant during the $2-4,6-8$, and $6-8 \mathrm{hr}$ time periods.

Oviposition Behavior. There was a suggestion that oviposition rates were reduced at the highest codlemone rates (Table 1); however, differences were not significant $(F=0.56 ; \mathrm{df}=4,88 ; P=$ $0.70)$. In the no-choice bioassay, oviposition was statistically similar ( $P=0.578, t$-test) between moths presented clean or Isomate C-treated waxed paper (mean eggs per female \pm SEM: untreated $[n=23], 20.7 \pm 3.9$; Isomate C-treated $[n=28]$, $17.9 \pm 3.7)$. When given a choice, codling moth females deposited significantly more $(P=0.0002$, $t$-test) eggs on untreated than on Isomate C-treated waxed paper (mean eggs per female $[n=24]$ \pm SEM: untreated, $23.3 \pm 2.9$; Isomate C-treated, $8.6 \pm 1.8)$.

Egg laying by codling moth females peaked during the 1st few hours of the scotophase (Fig. 4). The temporal pattern of oviposition did not differ between moths exposed to clean and codlemonepermeated air (Fig. 4). Summed over $24 \mathrm{~h}$, the total number of eggs laid per female was also similar between treatments (untreated $=49.1 \pm 19.8$, codlemone-treated $=45.4 \pm 26.3$ ).

\section{Discussion}

Codling moth activities such as calling, mating, and flight tend to be confined to scotophase (Wong et al. 1971, Niemczyk et al. 1977, Castrovillo and Cardé 1979, Knight et al. 1994). Castrovillo and Cardé (1979) determined the rhythm of mating and calling to be circadian. However, environmental conditions such as falling temperatures and cloud cover can shift these activities into the photophase (Castrovillo and Cardé 1979). In contrast, median oviposition rates have been reported to occur $2.5 \mathrm{~h}$ before dusk (Riedl and Loher 1980). The temporal pattern of calling observed in this study, in the presence and absence of codlemone, is in agreement with other studies, in that calling peaked after dusk and gradually decreased until the beginning of photophase, at which time calling

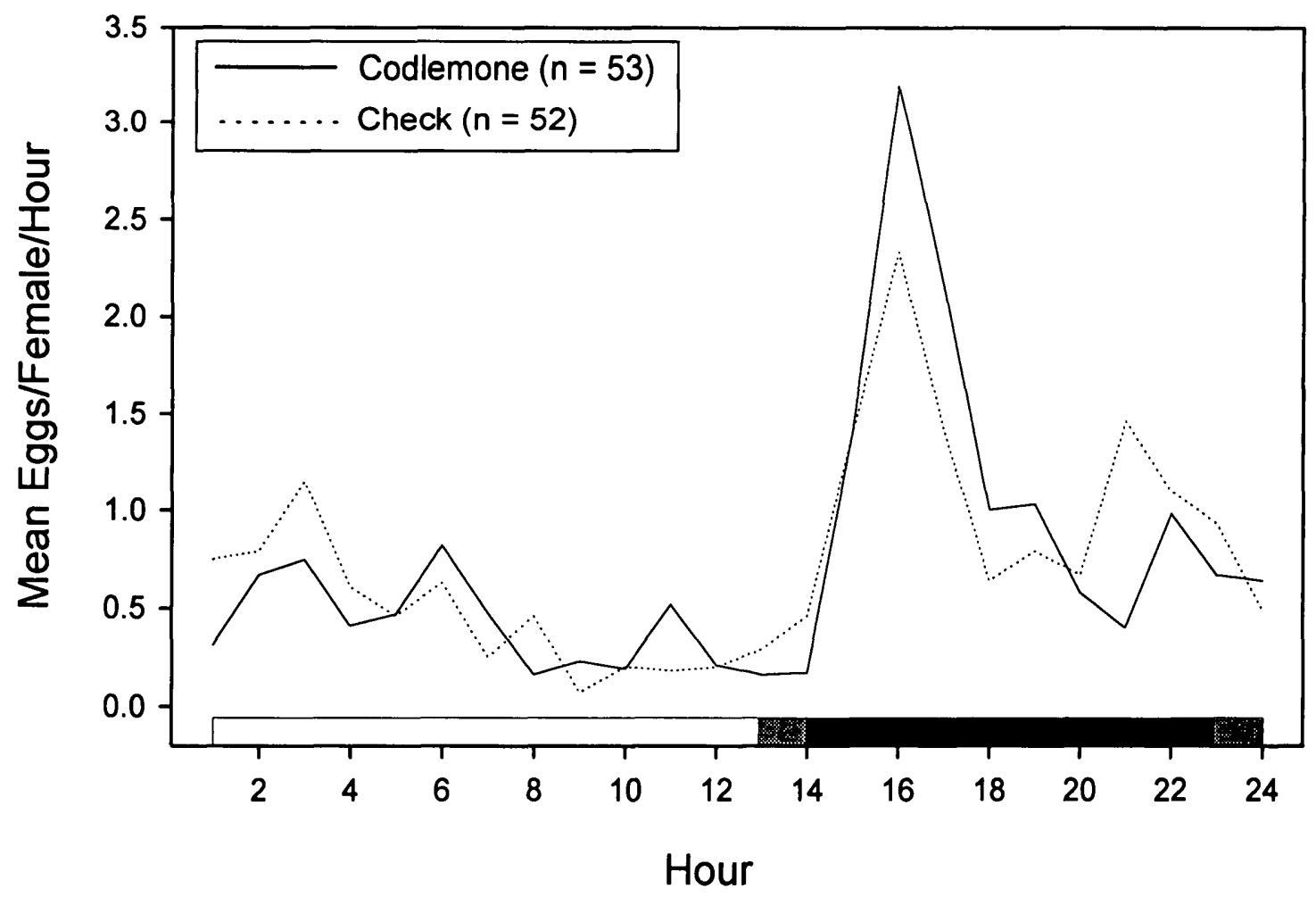

Fig. 4. Temporal pattern of oviposition by codling moths exposed to clean and codlemone-permeated air. 
is terminated (Niemczyk et al. 1977, Castrovillo and Cardé 1979). In this study, however, oviposition did not peak until after the beginning of the scotophase. Reasons for this shift relative to temporal patterns observed by Riedl and Loher (1980) are unclear. We considered that the use of laboratory-reared moths had led to a difference. However, field-collected moths tested by the same procedures except for the use of ambient light had an identical temporal pattern of oviposition (A.L.K., unpublished data). Based on results of a similar study with another tortricid, Choristoneura fumiferana (Clemens) (Palaniswamy and Seabrook 1985), we expected to observe a shift in the timing of codling moth female activities only in the presence of a pheromone component. The presence of the major pheromone component (codlemone), however, appeared to have no effect on the temporal patterns of oviposition and calling in this study.

In addition to observing a shift in the temporal calling pattern of C. fumiferana, Palaniswamy and Seabrook (1985) reported that the percentage of calling moths increased in the presence of a synthetic pheromone. When placed in sealed containers, calling rates of codling moth were similar between the check and codlemone treatment (Fig. 3A). Air within the sealed containers probably became fouled with female-produced pheromone soon after calling began. Females that detected their own pheromone may have responded by calling more frequently, leading to a lack of difference between the 2 treatments. This result prompted the development and use of a system that pulled air through arenas, thus removing some or all of the pheromone released by calling females. With this device, we determined that clean air moving at $8 \mathrm{~cm} / \mathrm{s}$ had negligible effect on calling (Fig. 3B) but that codling moth females exposed to moving codlemone-permeated air called more frequently than moths exposed to moving clean air (Fig. 3C).

Results of a previous study (A.L.K., unpublished data) indicated that caged codling moth females laid fewer eggs when placed in apple plots treated with Isomate $\mathrm{C}$ dispensers than without. This difference was not observed in the laboratory nochoice test, where statistically similar oviposition rates were observed between the control and codlemone treatment. Even across a wide range of codlemone dosage in laboratory no-choice tests, oviposition rates did not vary significantly, although there was a slight reduction in oviposition at the highest rate (Table 1). By caging several codling moth females together, Hilker (1989) investigated the influence of high sex pheromone concentrations on codling moth oviposition under the hypothesis that pheromone present at high enough levels would reduce egg deposition and subsequent larval competition. As in the current study, Hilker (1989) found no influence of pheromone presence on oviposition in a no-choice assay. The importance of amount of pheromone, or a primary component (codlemone) may not be fully understood, that is, a low pheromone or codlemone concentration may cause the same behavioral response as a high concentration. Palanaswamy and Seabrook (1978) reported that electroantennogram response of female $C$. fumiferana to a low rate of pheromone was not much different than response to a rate 10 times as high. This sort of information is lacking for the codling moth. In choice tests, females laid significantly more eggs on untreated than Isomate C-treated waxed paper, suggesting that gravid females will avoid a contaminated surface when provided a choice.

Perception of codlemone and 2 other pheromone components by codling moth females (Barnes et al. 1992) and modification of calling and oviposition behaviors by the presence of codlemone may have important implications in the use of mating disruption as a management technique. As suggested by Palanaswamy and Seabrook (1978), C. fumiferana females may use pheromone concentration as an indicator of population density, and high concentrations may trigger dispersal. It remains uncertain, however, if codling moth females in the field avoid pheromone or its principle component, codlemone. In the current study, gravid females were allowed a limited choice and chose an uncontaminated over a codlemone-contaminated surface for oviposition. Virgin females, however, were not allowed to disperse and responded to the presence of codlemone by increased calling, and perhaps moths compensate for apparent competition by this behavior rather than dispersal.

Codlemone concentrations have been shown by portable electroantennograph to be lower at the edges and in the upper strata of mating disrupted orchards (Milli and Dickler 1992). Codling moth females are active, and mate most frequently in the upper canopy (Weissling and Knight 1995). Therefore, mating disruptant dispensers applied low in the canopy may not sufficiently mask a potentially competing female. In addition, absorption of codlemone onto orchard foliage varies by proximity to dispensers applied for mating disruption (Karg et al. 1994) and gravid females may move to areas where concentrations are lower, such as the upper canopy or the edge of orchards. Thus, it may be important to treat orchard borders with more dispensers (Charmillot 1990) than the interior. A better understanding of pheromone ingredient distribution and adsorption on leaf surfaces within orchard canopies is essential, and together with information presented in this study could lead to more efficacious use of codlemone and other pheromone components for mating disruption.

\section{Acknowledgments}

We thank J. Turner and A. Rath for technical assistance, D. Horton for statistical advice, and $\mathrm{M}$. Weiss for designing the electrical controls for the oviposition device. The comments of D. Horton, S. Bloem, and R. Re- 
dak on an earlier version of the manuscript are also appreciated. This study was partially funded by the Washington State Tree Fruit Research Commission.

\section{References Cited}

Barnes, M. M., J. G. Millar, P. A. Kirseh, and D. C. Hawks. 1992. Codling moth (Lepidoptera: Tortricidae) control by dissemination of synthetic female sex pheromone. J. Econ. Entomol. 85: 1274-1277.

Batiste, W. C., W. H. Olsen, and A. Berlowitz. 1973. Codling moth: diel periodicity of catch in synthetic sex attractant vs. female-baited traps. Environ. Entomol. 2: 673-676.

Castrovillo, P. J., and R. T. Cardé. 1979. Environmental regulation of female calling and male response periodicities in the codling moth (Laspeyresia pomonella). J. Insect Physiol. 25: 659-667.

1980. Male codling moth (Laspeyresia pomonella) orientation to visual cues in the presence of pheromone and sequences of courtship behaviors. Ann. Entomol. Soc. Am. 73: 100-105.

Charmillot, P. J. 1990. Mating disruption technique to control codling moth in western Switzerland, pp. 165-182. In R. L. Ridgway, R. M. Silverstein, and M. N. Inscoe [eds.], Behavior-modifying chemicals for insect management. Marcel Dekker, New York.

Fluri, P., E. Mani, T. Wildbolz, and H. Arn. 1974. Untersuchungen über das Paarungsverhalten des Apfelwicklers (Laspeyresia pomonella L.) und über den Einfluss von künstlichen Sexuallockstoff auf die Kopulationshäufigkeit. Mitt. Schweiz. Entomol. Ges. 47: 253-259.

Hilker, M. 1989. Studies on the influence of larval faeces and sex pheromones on the oviposition of the codling moth, Laspeyresia pomonella (L.) (Lep., Tortricidae). J. Appl. Entomol. 107: 446-454.

Howell, J. F. 1991. Reproductive biology, pp. 157-174. In L.P.S. van der Geest and H. H. Evenhuis [eds.], Tortricid pests, their biology, natural enemies and control. Elsevier, Amsterdam.

Howell, J. F., A. L. Knight, T. R. Unruh, D. F. Brown, J. L. Krysan, C. R. Sell, and P. A. Kirsch. 1992. Control of codling moth in apple and pear with sex pheromone-mediated mating disruption. J. Econ. Entomol. 85: 918-925.

Hutt, R. B., and L. D. White. 1977. Mating response to visual stimulus in the male codling moth. Environ. Entomol. 6: 567-568.

Juckson, D. M. 1979. Codling moth egg distribution on unmanaged apple trees. Ann. Entomol. Soc. Am. 72: $361-368$.

Karg, G., D. M. Suckling, and S. J. Bradley. 1994. Absorption and release of pheromone of Epiphyas postvittana (Lepidoptera: Tortricidae) by apple leaves. J. Chem. Ecol. 20: 1825-1841.

Knight, A. L., M. Weiss, and T. Weissling. 1994. Diurnal patterns of adult activity of four orchard pests (Lepidoptera: Tortricidae) measured by timing trap and actograph. J. Agric. Entomol. 11: 125-136.

MeDonough, L. M. 1991. Controlled release of insect sex pheromones from a natural rubber substrate, pp. 106-124. In P. A. Hedin [ed.], Naturally occurring pest bioregulators. American Chemical Society, Washington, DC.

Milli, R., and E. Dickler. 1992. Distribution of pheromone in apple orchards where codling moth is controlled by mating disruption, pp. 140-144. In C. Ioriatti and $\mathrm{H}$. Arn [eds.], Use of pheromones and other semiochemicals in integrated control. Proc. International Organization for Biological and Integrated Control of Noxious Animals and Plants Working Group, IOBC/WPRS Bulletin 1992/XV/5, San Michele All'Adige, Italy.

Niemczyk, E., E. Mani, and Th. Wildbolz. 1977. Experiments on calling and mating of codling moths as a measure of competitiveness. Soc. Entomol. Suisse 5: 3-9.

Palaniswamy, P., and W. D. Seabrook. 1978. Behavioral responses of the female eastern spruce budworm Choristoneura fumiferana (Lepidoptera: Tortricidae) to the sex pheromone of her own species. J. Chem. Ecol. 4: 649-655.

1985. The alteration of calling behaviour by female Choristoneura fumiferana when exposed to synthetic pheromone. Entomol. Exp. Appl. 37: 13-16.

Pfeiffer, D. G., W. Kaakeh, J. C. Killian, M. W. Lachance, and $P$. Kirsch. 1993. Mating disruption for control of damage by codling moth in Virginia apple orchards. Entomol. Exp. Appl. 67: 57-64.

Riedl, H., and W. Loher. 1980. Circadian control of oviposition in the codling moth, Laspeyresia pomonella, Lepidoptera: Olethreutidae. Entomol. Exp. Appl. 27: 38-49.

Roelofs, W., L. A. Comeau, A. Hill, and G. Milicevic. 1971. Sex attractant of the codling moth: characterization with electroantennogram technique. Science (Washington, DC) 174: 297-299.

SAS Institute. 1985. SAS user's guide: statistics, 5 th ed. SAS Institute, Cary, NC.

Weissling, T. J., and A. L. Knight. 1995. Vertical distribution of codling moth adults in pheromone-treated and untreated plots. Entomol. Exp. Appl. (in press).

Wong, T.T.Y., M. L. Cleveland, D. F. Ralston, and D. G. Davis. 1971. Time of sexual activity of codling moths in the field. J. Econ. Entomol. 64: 553-554.

Received for publication 15 May 1995; accepted 21. August 1995. 